\title{
KEMAMPUAN BERPIKIR REFLEKTIF SISWA DENGAN METODE PEMBELAJARAN THINKING ALOUD PAIR PROBLEM SOLVING (TAPPS) BERBANTUAN MEDIA LKPD PADA MATERI BANGUN RUANG BALOK DAN KUBUS
}

\author{
Nadlifah Alqonita ${ }^{1}$ \\ ${ }^{1} M T$ s Ma'arif Sidomukti gresik \\ Email: ${ }^{1}$ nadhifaalqonita@gmail.com
}

\begin{abstract}
Abstrak
Penelitian kombinasi ini dilatar belakangi oleh rendahnya kemampuan siswa dalam hal berpikir reflektif. Penelitian ini bertujuan untuk (1) mengetahui adanya perbedaan kemampuan berpikir reflektif pada kelas kontrol dengan pembelajaran konvensional dan pada kelas eksperimen dengan menggunakan metode Thinking Aloud Pair Problem Solving; dan (2) mendeskripsikan kemampuan berpikir reflektif peserta didik setelah diterapkan dengan pembelajaran menggunakan metode Thinking Aloud Pair Problem Solving materi bangun ruang balok dan kubus MTs Ma'arif Sidomukti gresik. Jenis penelitian yang digunakan adalah metode kombinasi (mix method) dengan sequential explanatory design. Pengambilan sampel dalam penelitian ini ditentukan berdasarkan teknik Cluster Random Sampling diperoleh kelas VIII-1 sebagai kelas kontrol dan VIII-2 sebagai kelas eksperimen. Data kuantitatif diperoleh melalui soal tes kemampuan berpikir reflektif, analisis data yang digunakan yaitu dengan menggunakan uji normalitas, uji homogenitas, dan uji $t$. sedangkan pengumpulan data kualitatif diperoleh dari wawancara, observasi, dan catatan lapangan guna untuk mendukung data kuantitatif yang digunakan. Subjek penelitian kualitatif terdiri dari 6 siswa yang masing-masing kelas terdiri dari siswa yang berkemampuan tinggi, sedang, dan rendah. Analisis data hasil post-test kemampuan berpikir reflektif siswa yang berkemampuan rendah sebesar $10 \%$, sedang sebesar 43,33\%, tinggi sebesar 46,67\%. Sedangkan rata-rata nilai siswa termasuk dalam kategori tinggi yaitu $83 \%$. Dari beberapa analisis data tersebut menunjukkan bahwa kemampuan berpikir reflektif masuk dalam kategori tinggi setelah penerapan dengan metode pembelajaran Thinking Aloud pair Problem Solving berbantuan media LKPD.
\end{abstract}

Kata-kata kunci: kemampuan berpikir reflektif, metode thinking aloud pair problem solving, bangun ruang balok dan kubus.

\section{PENDAHULUAN}

Matematika merupakan salah satu ilmu yang menjadi dasar bagi ilmu-ilmu yang lain. Disamping itu, sasaran dalam pembelajaran matematika di setiap jenjang pedidikan diantaranya adalah dengan mengembangkan kemampuan peserta didik dalam berpikir secara matematis. Kemampuan berpikir matematis ini sangat diperlukan bagi seluruh peserta didik agar peserta didik dapat memahami konsep serta dapat memecahkan masalah matematika dan menerapkannya dalam kehidupan sehari-hari.

Dalam proses berpikir matematis, terdapat kemampuan berpikir yang ada pada setiap orang. Salah satu bagian dari kemampuan berpikir matematis seseorang terdapat kemampuan berpikir reflektif matematis. Meisner (dalam Rasyid, 2017:172) menyatakan bahwa perkembangan berpikir reflektif merupakan pusat pendidikan matematika. Ini menunjukkan bahwa perkembangan berpikir reflektif telah menjadi sorotan dan merupakan hal yang penting dalam pendidikan matematika dan merupakan unsur yang paling penting untuk belajar secara efektif.

Berdasarkan hasil wawancara oleh beberapa sumber informasi salah satu pendidik di MTs Ma'arif Sidomukti Gresik dan berdasarkan hasil pengamatan peneliti secara langsung di lapangan, kemampuan berpikir reflektif ini jarang sekali dikembangkan di tingkat Sekolah Menengah Pertama 
(SMP) terutama di MTs Ma'arif Sidomukti Gresik. Hal ini mengakibatkan kemampuan proses berpikir reflektif tersebut masih tergolong rendah. Rendahnya kualitas kemampuan matematika peserta didik tidak terlepas dari penyelenggaraan proses pembelajaran di kelas. Banyak faktor yang mempengaruhi suksesnya proses pembelajaran tersebut, diantaranya faktor guru, peserta didik, model pembelajaran yang digunakan, lingkungan belajar, dan sarana prasarana.

Upaya untuk mengantisipasi masalah pembelajaran yang berkelanjutan diperlukan seorang pendidik yang kreatif dan inovatif dalam memilih model atau metode pembelajaran sehingga akan tercipta suasana pembelajaran yang menyenangkan bagi peserta didik dan peserta didik dapat menerima pelajaran dengan baik serta dapat meningkatkan kemampuan berpikir reflektif peserta didik dalam memecahkan suatu masalah. Salah satu pembelajaran yang diharapkan dapat membentuk kemampuan matematika peserta didik dalam berfikir reflektif untuk memecahkan masalah dan aktif melibatkan peserta didik dalam pembelajaran adalah Thinking Aloud Pair Problem Solving (TAPPS).

Menurut Lochhead \& Whimbey (dalam Jhonson \& Chung: 1999) Thinking Aloud Pair Problem Solving cenderung menekankan pada aplikasi pemecahan masalah umum dalam situasi kehidupan sehari-hari. Pembelajaran dengan menggunakan metode Thinking Aloud Pair Problem Solving (TAPPS) ini diharapkan dapat memaksimalkan kemampuan berpikir reflektif peserta didik dalam memecahkan masalah.

Tidak hanya metode yang digunakan dalam pembelajaran matematika di kelas, agar pembelajaran berjalan dengan maksimal perlu diterapkan media yang menarik minat peserta didik dalam mengikuti pembelajaran di kelas. Lembar Kerja Peserta didik (LKPD) merupakan salah satu sarana untuk mempermudah dan membantu dalam kegiatan belajar mengajar sehinggga akan terbentuk interaksi yang efektif antara peserta didik dan pendidik yang dapat meningkatkan motivasi peserta didik dalam peningkatan hasil belajarnya (Asdaniar, 2017:161).

Berdasarkan uraian di atas, maka peneliti tertarik untuk melakukan penelitian dengan judul "Kemampuan Berpikir Reflektif Peserta didik dengan Menggunakan Metode Pembelajaran Thinking Aloud Pair Problem Solving (TAPPS) Berbantuan Media LKPD pada Materi Bangun Ruang Balok dan Kubus Kelas VIII MTS Ma'arif Sidomukti Gresik”.

Berdasarkan uraian di atas, rumusan masalah dalam penelitian ini adalah: (1) Apakah terdapat perbedaan kemampuan berpikir reflektif peserta didik dengan menggunakan metode pembelajaran Thinking Aloud Pair Problem Solving (TAPPS) berbantuan media LKPD dan yang menggunakan metode pembelajaran konvensional pada materi bangun ruang balok dan kubus kelas VIII di MTs Ma'arif Sidomukti Gresik?; dan (2) Bagaimana kemampuan berpikir reflektif peserta didik setelah pembelajaran dengan penerapan menggunakan metode Thinking Aloud Pair Problem Solving (TAPPS) berbantuan media LKPD pada materi bangun ruang balok dan kubus kelas VIII di MTs Ma'arif Sidomukti Gresik

Sesuai dengan rumusan masalah di atas, tujuan penelitian ini adalah: (1) Mengetahui adanya perbedaan kemampuan berpikir reflektif peserta didik dengan menggunakan metode pembelajaran Thinking Aloud Pair Problem Solving (TAPPS) berbantuan media LKPD dan yang menggunakan metode pembelajaran konvensional pada materi bangun ruang balok dan kubus kelas VIII di MTs Ma'arif Sidomukti Gresik; dan (2) Mendeskripsikan kemampuan berpikir reflektif peserta didik dengan penerapan menggunakan metode pembelajaran Thinking Aloud Pair Problem Solving (TAPPS) berbantuan media LKPD pada materi bangun ruang balok dan kubus kelas VIII di MTs Ma'arif Sidomukti Gresik.

Menurut Surbeck (dalam Noer, 2010:39) mengutarakan bahwa kemampuan berpikir reflektif adalah kemampuan mengidentifikasi apa yang sudah diketahui, menerapkan pengetahuan yang dimiliki dalam situasi yang lain, memodifikasi pemahaman berdasarkan informasi dan pengalamanpengalaman baru yang meliputi tiga fase/ tingkat yaitu, (1) fase reacting; (2) fase Comparing; (3) fase Contemeplating. Dalam penelitian ini, kemampuan berpikir reflektif yang akan diukur terdapat 5 indikator dalam 3 fase/tingkat yaitu (1) fase reacting dengan indikator menyebutkan apa yang 
diketahui dan apa yang ditanyakan serta menghubungkannya; (2) fase reacting dengan indikator menjelaskan kecukupan informasi dan menjelaskan metode yang efektif untuk menyelesaikan soal; (3) fase Comparing dengan indikator menjelaskan, menghubungan serta mengkaitkan masalah yang ditanyakan dengan masalah yang pernah dihadapi; (4) fase Contemplating dengan indikator menentukan maksud dan mendeteksi kebenaran jawaban pada penentuan jawaban; (5) fase Contemplating dengan indikator mendeteksi dan memperbaiki jika terjadi kesalahan serta menyimpulkan persoalan dengan benar

\section{METODE}

Penelitian ini menggunakan dua pendekatan yaitu pendekatan kuantitatif dan pendekatan kualitatif Metode penelitian yang digunakan dalam penelitian ini adalah metode kombinasi (Mixed Methods) dengan jenis sequential explanatory design. Penelitian ini dilaksanakan di MTs ma'arif Sidomukti Gresik. Adapun subjek penelitiannya adalah siswa kelas VIII-1 dan VIII-2 yang masingmasing berjumlah 30 siswa.

Adapun teknik pengumpulan data dalam penelitian ini dibagi menjadi dua yaitu teknik pengumpulan data secara kuantitatif dan teknik pengumpulan data secara kualitatif. Teknik pengumpulan data secara kuantitaif dilakukan dengan tes berupa soal uraian untuk mengukur kemampuan berpikir reflektif. Sedangkan teknik pengumpulan data secara kualitatif dilakukan dengan: (1) wawancara, digunakan untuk mendapatkan informasi lebih mendalam tentang keadaan kelas tersebut yang dilakukan sebelum dan sesudah penelitian, (2) observasi, digunakan untuk mengamati aktivitas guru dan siswa selama proses pembelajaran berlangsung dan (3) catatan lapangan, digunakan untuk melengkapai data yang tidak tercantum dalam lembar observasi.

Instrumen penelitian kuantitatif dalam penelitian ini menggunakan tes awal dan tes akhir yang merupakan tes penelitian untuk mengukur kemampuan berpikir reflektif peserta didik. Sedangkan intrumen penelitian kualitatif dalam penelitian ini adalah sebagai berikut: (1) pedoman wawancara, (2) lembar observasi, terdiri dari lembar observasi aktivitas guru dan lembar observasi aktivitas siswa. Observasi dilaksanakan selama proses pembelajaran berlangsung dan (3) pedoman catatan lapangan, diisi oleh dua pengamat yaitu guru mata pelajaran matematika kelas VIII beserta teman sejawat.

Analisis data penelitian kuantitatif terdiri dari: (1) analisis data pre-test yang meliputi uji normalitas, uji homogenitas dan uji kesamaan rata-rata kemampuan awal, serta (2) analisis data post-test yang meliputi uji normalitas, uji homogenitas dan uji hipotesis dengan menggunakan softwere SPSS 22 untuk mengetahui perbedaan kemampuan berpikir reflektif menggunakan metode pembelajaran Thinking Aloud Pair Problem Solving berbantuan media LKPD dengan menggunakan metode pembelajaran konvensional. Sedangkan analisis penelitian kualitatif terdiri dari: (1) analisis data sebelum dilapangan yang dilakukan dengan observasi kegiatan awal serta cara wawancara terhadap guru, (2) analisis data selama dilapangan model Miles dan Huberman yang meliputi reduksi data, penyajian data, dan penarikan kesimpulan serta uji keabsahan data dengan menggunakan teknik triangulasi.

Analisis data penelitian campuran (kuantitatif dan kualitatif) dilakukan dengan cara membandingkan data kuantitatif hasil penelitian pada tahap pertama dan data kualitatif hasil penelitian tahap kedua. Melalui analisis data ini akan diperoleh informasi keduanya saling melengkapi, memperluas, memperdalam atau malah bertentangan.

\section{HASIL}

Dalam penelitian ini peneliti menggunakan tes uraian yang sebelumnya sudah di lakukan uji validitas dan reliabilitas untuk dapat digunakan sebagai instrumen pengumpulan data kuantitatif. Untuk memperoleh soal yang valid, Validitas yang dilakukan dalam penelitian ini adalah validitas logis dan validitas empiris. validitas logis dilakukan oleh dua validator yakni dosen pendidikan 
matematika dan seorang praktisi guru matematika MTs Ma'arif Sidomukti Gresik. Pengujian validitas empiris dilakukan dengan menguji-cobakan soal tes kemampuan berpikir reflektif pada kelas VIII-3 MTs Ma'arif Sidomukti Gresik. Sedangkan untuk intrumen pengumpulan data kualitatif menggunakan hasil observasi, wawancara dan catatan lapangan. Berdasarkan uji validitas soal pre-test dan post-tets yang dilakukan pada 5 butir soal uraian yang telah diuji cobakan maka dapat disimpulkan bahwa kelima butir soal valid dan dapat digunakan dengan sedikit revisi

\section{Hasil Analisis Data Kuantitatif}

Berdasarkan hasil analisis data pre-test dan pos-test, dapat diketahui bahwa data pre-test dan post-test kelas eksperimen dan kelas kontrol telah berdistribusi normal. Sedangkan untuk uji kesamaan rata-rata data pre-test diperoleh nilai $\mathrm{Sig}=0,202>0,025$. Dengan demikian, $\mathrm{H}_{0}$ diterima sehingga tidak terdapat perbedaan kemampuan awal antara kelas eksperimen dan kelas kontrol atau kemampuan awal kedua kelas sama. Hal ini menunjukkan bahwa kemampuan awal berpikir reflektif peserta didik kelas eksperimen sama dengan kemampuan awal berpikir reflektif peserta didik kelas kontrol. Sedangkan berdasarkan hasil analisis uji hipotesis dua pihak data post-test diperoleh nilai $\mathrm{Sig}=0,005<0,025$. Dengan demikian, $\mathrm{H}_{0}$ ditolak sehingga terdapat perbedaan kemampuan berpikir reflektif antara kelas eksperimen dengan kelas kontrol. Jadi dapat disimpulkan bahwa terdapat perbedaan kemampuan berpikir reflektif yang signifikan antara peserta didik yang diajar dengan metode pembelajaran Thinking Aloud Pair Problem Solving dan peserta didik yang diajar dengan metode konvensional

Table 1: Deskripsi Kemampuan Berpikir Reflektif Peserta Didik

\begin{tabular}{lcccc}
\hline \multirow{2}{*}{ Statistik } & \multicolumn{2}{c}{ Kelas } \\
\cline { 2 - 5 } & \multicolumn{2}{c}{ Eksperimen } & \multicolumn{2}{c}{ Kontrol } \\
\cline { 2 - 5 } & Pre-test & Post-test & Pre-test & Post-test \\
\hline Jumlah peserta didik & 30 & 30 & 30 & 30 \\
\hline Jumlah total nilai peserta didik & 960 & 2490 & 1150 & 2165 \\
\hline Mean & 32 & 83 & 38,33 & 72,17 \\
\hline Standart Deviation & 15,57 & 12,14 & 21,91 & 16,38 \\
\hline
\end{tabular}

Berdasarkan tabel 1 dapat diketahui bahwa peserta didik kelas eksperimen, memperoleh nilai rata-rata 83. Pada kelas kontrol, diperoleh nilai rata-rata 72,12 Berdasarkan tabel, maka dapat disimpulkan bahwa terdapat perbedaan nilai rata-rata kemampuan berpikir reflektif peserta didik pada kelas eskperimen yang diberikan pembelajaran dengan metode Thinking Aloud Pair Problem Solving berbantuan media LKPD dan kelas kontrol yang diberikan pembelajaran dengan metode konvensional.

\section{Hasil Analisis Data Kualitatif}

Pada analisis data kualitatif, peneliti memberikan analisis data kualitatif yang meliputi analisis data sebelum penelitian, selama penelitian, dan setelah penelitian. analisis data sebelum penelitian berupa data hasil wawancara guru. Analisis data selama penelitian berupa data hasil observasi dan catatan lapangan. Sedangkan data setelah penelitian berupa data hasil wawancara peserta didik kemampuan berpikir reflektif peserta didik kelas eksperimen dan kelas kontrol. Berikut uraian data kualitatif sebelum, selama, dan setelah penelitian.

Tabel 2 Hasil Lembar Observasi Kegiatan Guru Kelas Eksperimen

\begin{tabular}{|c|c|c|c|c|c|c|c|}
\hline \multirow{3}{*}{ No } & \multirow[t]{3}{*}{ Kegiatan Guru } & \multicolumn{3}{|c|}{ Pertemuan Pertama } & \multicolumn{3}{|c|}{ Pertemuan Kedua } \\
\hline & & \multirow{2}{*}{ Skor Max } & \multicolumn{2}{|c|}{ Skor Pengamat } & \multirow{2}{*}{ Skor Max } & \multicolumn{2}{|c|}{ Skor Pengamat } \\
\hline & & & 1 & 2 & & 1 & 2 \\
\hline 1 & Kegiatan Awal & 25 & 21 & 21 & 25 & 21 & 21 \\
\hline 2 & Kegiatan Inti & 20 & 16 & 15 & 20 & 14 & 16 \\
\hline 3 & Kegiatan Akhir & 15 & 13 & 14 & 15 & 12 & 12 \\
\hline Jumlah & & 60 & 50 & 50 & 60 & 47 & 49 \\
\hline
\end{tabular}




\begin{tabular}{lcccccc}
\hline Prosentase kegiatan guru & $100 \%$ & $83,33 \%$ & $83,33 \%$ & $100 \%$ & $78,33 \%$ & $81,67 \%$ \\
\hline Taraf Keberhasilan & Sangat & Sangat & Sangat & Sangat & Baik & Sangat \\
& Baik & Baik & Baik & Baik & Baik \\
\hline Rata-rata & & & $81,67 \%$ (Baik) & \\
\hline
\end{tabular}

Tabel 3: Hasil Lembar Observasi Kegiatan Guru Kelas Kontrol

\begin{tabular}{|c|c|c|c|c|c|c|c|}
\hline \multirow{3}{*}{ No } & \multirow[t]{3}{*}{ Kegiatan Guru } & \multicolumn{3}{|c|}{ Pertemuan Pertama } & \multicolumn{3}{|c|}{ Pertemuan Kedua } \\
\hline & & \multirow{2}{*}{$\begin{array}{l}\text { Skor } \\
\text { Max }\end{array}$} & \multicolumn{2}{|c|}{ Skor Pengamat } & \multirow[t]{2}{*}{ Skor Max } & \multicolumn{2}{|c|}{ Skor Pengamat } \\
\hline & & & 1 & 2 & & 1 & 2 \\
\hline 1 & Kegiatan Awal & 25 & 20 & 20 & 25 & 19 & 20 \\
\hline 2 & Kegiatan Inti & 40 & 32 & 32 & 40 & 32 & 32 \\
\hline 3 & Kegiatan Akhir & 15 & 12 & 11 & 15 & 12 & 11 \\
\hline \multicolumn{2}{|c|}{ Jumlah } & 80 & 64 & 63 & 80 & 63 & 63 \\
\hline \multicolumn{2}{|c|}{ Prosentase kegiatan guru } & $100 \%$ & $80,00 \%$ & $78,75 \%$ & $100 \%$ & $78,75 \%$ & $78,75 \%$ \\
\hline \multicolumn{2}{|c|}{ Taraf Keberhasilan } & $\begin{array}{c}\text { Sangat } \\
\text { Baik }\end{array}$ & Baik & Baik & Baik & Baik & Baik \\
\hline
\end{tabular}

Berdarkan tabel 2 dan tabel 3 maka dapat disimpulkan bahwa pelaksanaan pembelajaran dengan metode TAPPS (Thinking Aloud Pair Problem Solving) dengan berbantuan media LKPD dan model pembelajaran konvensional sudah terlaksana dengan baik.

Tabel 4: Hasil Lembar Observasi Kegiatan Peserta didik Kelas Eksperimen

\begin{tabular}{|c|c|c|c|c|c|c|}
\hline \multirow[t]{3}{*}{ Kegiatan Guru } & \multicolumn{3}{|c|}{ Pertemuan Pertama } & \multicolumn{3}{|c|}{ Pertemuan Kedua } \\
\hline & \multirow{2}{*}{$\begin{array}{l}\text { Skor } \\
\text { Max }\end{array}$} & \multicolumn{2}{|c|}{ Skor Pengamat } & \multirow{2}{*}{$\begin{array}{l}\text { Skor } \\
\text { Max }\end{array}$} & \multicolumn{2}{|c|}{ Skor Pengamat } \\
\hline & & 1 & 2 & & 1 & 2 \\
\hline Kegiatan Awal & 25 & 23 & 20 & 25 & 24 & 22 \\
\hline Kegiatan Inti & 35 & 32 & 28 & 35 & 34 & 30 \\
\hline Kegiatan Akhir & 20 & 17 & 15 & 20 & 17 & 18 \\
\hline Jumlah & 80 & 72 & 63 & 80 & 75 & 70 \\
\hline Prosentase kegiatan guru & $100 \%$ & $90 \%$ & $78,75 \%$ & $100 \%$ & $93,75 \%$ & $87,5 \%$ \\
\hline Taraf Keberhasilan & $\begin{array}{c}\text { Sangat } \\
\text { Baik }\end{array}$ & $\begin{array}{c}\text { Sangat } \\
\text { Baik }\end{array}$ & Baik & $\begin{array}{c}\text { Sangat } \\
\text { Baik }\end{array}$ & $\begin{array}{c}\text { Sangat } \\
\text { Baik }\end{array}$ & $\begin{array}{c}\text { Sangat } \\
\text { Baik }\end{array}$ \\
\hline Rata-rata & & & $87,5 \%$ & angat $\mathrm{Bc}$ & & \\
\hline
\end{tabular}

Tabel 5: Hasil Lembar Observasi Kegiatan Peserta didik Kelas Kontrol

\begin{tabular}{|c|c|c|c|c|c|c|c|}
\hline \multirow{3}{*}{ No } & \multirow[t]{3}{*}{ Kegiatan Guru } & \multicolumn{3}{|c|}{ Pertemuan Pertama } & \multicolumn{3}{|c|}{ Pertemuan Kedua } \\
\hline & & \multirow[t]{2}{*}{ Skor Max } & \multicolumn{2}{|c|}{ Skor Pengamat } & \multirow{2}{*}{$\begin{array}{l}\text { Skor } \\
\text { Max }\end{array}$} & \multicolumn{2}{|c|}{ Skor Pengamat } \\
\hline & & & 1 & 2 & & 1 & 2 \\
\hline 1 & Kegiatan Awal & 20 & 15 & 14 & 20 & 16 & 15 \\
\hline 2 & Kegiatan Inti & 35 & 25 & 25 & 35 & 27 & 26 \\
\hline 3 & Kegiatan Akhir & 20 & 18 & 15 & 20 & 16 & 15 \\
\hline \multicolumn{2}{|c|}{ Jumlah } & 75 & 58 & 54 & 75 & 58 & 56 \\
\hline \multicolumn{2}{|c|}{ Prosentase kegiatan guru } & $100 \%$ & $77,3 \%$ & $72 \%$ & $100 \%$ & $78,67 \%$ & $74,67 \%$ \\
\hline \multicolumn{2}{|c|}{ Taraf Keberhasilan } & $\begin{array}{c}\text { Sangat } \\
\text { Baik }\end{array}$ & Baik & Baik & $\begin{array}{c}\text { Sangat } \\
\text { Baik }\end{array}$ & Baik & Baik \\
\hline
\end{tabular}

Berdasarkan hasil yang diperoleh dari lembar observasi peserta didik pada Tabel 4 dan Tabel 5 maka dapat disimpulkan bahwa aktivitas peserta didik dalam pembelajaran menggunakan 
metode TAPPS (Thinking Aloud Pair Problem Solving) dengan berbantuan media LKPD dan model pembelajaran konvensional sudah dikategorikan baik.

Berdasarkan hasil catatan lapangan proses pembelajaran pada kelas eksperimen dapat disimpulkan bahwa proses pembelajaran sudah baik. Hal ini, didukung oleh perilaku peserta didik yang baik, tanggapan peserta didik yang positif dan menunjukkan sikap semangat saat melakukan pembelajaran, keseriusan peserta didik dalam mengerjakan dan memperhatikan pembelajaran serta keadaan kelas yang kondusif didukung dengan respon peserta didik yang antusias dalam mengikuti kegiatan pembelajaran. Sedangkan pada kelas kontrol proses pembelajaran cukup baik. Hal ini didukung oleh perilaku peserta didik yang baik, tanggapan peserta didik yang positif dan semangat saat melakukan pembelajaran masih kurang, keseriusan peserta didik dalam mengerjakan cukup baik meskipun keadaan kelas kondusif.

Tabel 7: Data Hasil Wawancara Subjek Kelas Eksperimen

\begin{tabular}{ccl}
\hline No & Prosentase & \\
\hline 1 & $83,33 \%$ & $\begin{array}{l}\text { Subjek menyatakan bahwa mereka merasa senang mengikuti pembelajaran menggunakan } \\
\text { metode TAPPS (Thinking Aloud Pair Problem Solving) berbantuan media LKPD }\end{array}$ \\
\hline 2 & $83,33 \%$ & $\begin{array}{l}\text { Subjek menyatakan bahwa mereka merasa senang mengikuti proses pembelajaran dengan } \\
\text { berpasangkan dan berkelompok karena dapat berdiskusi dengan teman kelompok }\end{array}$ \\
\hline 3 & $66,67 \%$ & $\begin{array}{l}\text { Subjek menyatakan bahwa mereka dapat memahami materi pembelajaran dengan } \\
\text { menggunakan pembelajaran berpasangan dan berkelompok karena dengan berkelompok } \\
\text { mereka bisa berdiskusi dan saling bertukar pikiran }\end{array}$ \\
\hline 4 & $83,33 \%$ & $\begin{array}{l}\text { Subjek menyatakan bahwa setelah menggunakan pembelajaran dengan metode TAPPS } \\
\text { (Thingking Aloud Pair Problem Solving) berbantuan media LKPD merasa lebih semangat } \\
\text { lagi dalam mengikuti pembelajara }\end{array}$ \\
\hline 5 & $66,67 \%$ & $\begin{array}{l}\text { Subjek menyatakan bahwa awalnya mereka merasa kesulitan dalam menyelesaikan suatu } \\
\text { permasalahan dalam memecahkan masalah tetapi setelah berpasangan dan berdiskusi } \\
\text { mereka mampu menyelesaikan kesulitan yang ada pada soal tersebut. }\end{array}$ \\
\hline 6 & $66,67 \%$ & $\begin{array}{l}\text { Subjek menyatakan bahwa dengan menggunakan metode TAPPS (Thinking Aloud Pair } \\
\text { Problem Solving) berbantuan media LKPD mempermudah mereka dalam menyelesaikan } \\
\text { soal pemecahan masalah yang diberikan karena bisa bekerjasama dengan teman } \\
\text { kelompoknya/ teman sepasangnya. }\end{array}$ \\
\hline 7 & $66,67 \%$ & $\begin{array}{l}\text { Subjek menyatakan bahwa tugas yang diberikan dapat membuat mereka mencetuskan } \\
\text { banyak ide, gagasan yang baru dan membuat mereka lebih meningkat proses berpikirnya. }\end{array}$ \\
\hline 8 & $83,33 \%$ & $\begin{array}{l}\text { Subjek menyatakan bahwa mereka bisa menjawaban ataupun bertanya yang bermacam- } \\
\text { macam, mengidentifikasi suatu masalah secara detail, mendeteksi dan memperbaiki jika } \\
\text { terjadi kesalahan dalam penentuan jawaban serta dapat menyimpulkan permasalahan } \\
\text { tersebut dengan benar. }\end{array}$ \\
\hline
\end{tabular}

Pada hasil wawancara terdapat dua rata-rata yaitu rata-rata peserta didik yang sudah memenuhi indikator dan rata-rata peserta didik yang belum memenuhi indikator. Peserta didik yang sudah memenuhi indikator berpikir reflektif sebanyak $75 \%$ Peserta didik yang belum memenuhi indikator berpikir reflektif matematis sebanyak $25 \%$

Tabel 4.27: Data Hasil Wawancara Subjek Kelas Kontrol

\begin{tabular}{ccl}
\hline No & Prosentase & \\
\hline 1 & $83,33 \%$ & $\begin{array}{l}\text { Subjek menyatakan bahwa mereka merasa senang mengikuti pembelajaran } \\
\text { menggunakan model pembelajaran konvensional }\end{array}$ \\
\hline 2 & $33,33 \%$ & $\begin{array}{l}\text { Subjek menyatakan bahwa mereka merasa senang mengikuti proses pembelajaran } \\
\text { menggunaka model pembelajaran konvensional karena guru menjelaskan secara } \\
\text { langsung dan mereka dapat memahami materi }\end{array}$ \\
\hline 3 & $33,33 \%$ & $\begin{array}{l}\text { Subjek menyatakan bahwa dengan model konvensional memudahkan mereka dalam } \\
\text { pembelajaran matematika }\end{array}$ \\
\hline 4 & $50 \%$ & $\begin{array}{l}\text { Subjek menyatakan bahwa setelah menggunakan pembelajaran dengan model merasa } \\
\text { lebih semangat lagi dalam mengikuti pembelajaran }\end{array}$ \\
\hline
\end{tabular}




\begin{tabular}{ccl}
\hline 5 & $50 \%$ & $\begin{array}{l}\text { Subjek menyatakan bahwa mereka merasa kesulitan dalam meneyelesaikan persoalan } \\
\text { dalam memecahkan masalah. }\end{array}$ \\
\hline 6 & $33,33 \%$ & $\begin{array}{l}\text { Subjek menyatakan bahwa tugas yang diberikan dapat memacu aktivitas mereka karena } \\
\text { hanya ada soal tanpa berdiskusi }\end{array}$ \\
\hline 7 & $33,33 \%$ & $\begin{array}{l}\text { Subjek menyatakan bahwa tugas yang diberikan dapat membuat mereka mencetuskan } \\
\text { banyak ide, gagasan yang baru dan membuat mereka lebih meningkat proses } \\
\text { berpikirnya. }\end{array}$ \\
\hline 8 & $50 \%$ & $\begin{array}{l}\text { Subjek menyatakan bahwa mereka bisa bertanya yang bermacam-macam, } \\
\text { mengidentifikasi suatu masalah secara detail, mendeteksi dan memperbaiki jika terjadi } \\
\text { kesalahan dalam penentuan jawaban serta dapat menyimpulkan permasalahan tersebut } \\
\text { dengan benar. }\end{array}$ \\
\hline $\begin{array}{c}\text { Rata- } \\
\text { rata }\end{array}$ & $58,335 \%$ & $\begin{array}{l}\text { Peserta didik sudah memenuhi kelima indikator berpikir reflektif matematis sehingga } \\
\text { dapat menjawab soal dengan benar }\end{array}$ \\
\cline { 2 - 3 } & $\begin{array}{l}\text { Subjek belum memenuhi kelima indikator berpikir reflektif matematis sehingga } \\
\text { menjawab soal masih salah }\end{array}$ \\
\hline
\end{tabular}

Pada hasil wawancara terdapat dua rata-rata yaitu rata-rata peserta didik yang sudah memenuhi indikator dan rata-rata peserta didikyang belum memenuhi indikator. Peserta didik yang sudah memenuhi indikator berpikir reflektif sebanyak 41,665\%. Peserta didik yang belum memenuhi indikator berpikir reflektif sebanyak 58,335\%.

\section{Analisis Data Kuantitatif dan Kualitatif}

Berdasarkan analisis data kuantitatif hasil tes kemampuan berpikir reflektif peserta didik diukur menggunakan hasil post-test. Hasil uji hipotesis dengan perhitungan menggunakan software SPSS 20 diperoleh nilai Sig 2-tailed $=0,005$. Jelas $\mathrm{Sig}=0,005<0,05$ sehingga $H_{0}$ ditolak, artinya terdapat perbedaan kemampuan berpikir reflektif antara peserta didik kelas eksperimen menggunakan model pembelajaran TAPPS (Thinking Aloud Pair Problem Solving) berbantuan media LKPD dan kelas kontrol menggunakan model konvensional pada materi bangun ruang balok dan kubus kelas VIII MTs Ma'arif Sidomukti Gresik Tahun Pelajaran 2017/2018.

Berdasarkan analisis data kualitatif diperoleh hasil pada kelas eksperimen untuk indikator berpikir reflektif, 1) fase Reacting dengan indikator menyebutkan apa yang diketahui dan apa yang ditanyakan serta menghubungkannya mencapai $89,17 \%$; 2) fase Reacting dengan indikator menjelaskan kecukupan informasi dan menjelaskan metode yang efektif untuk menyelesaikan soal mencapai 78,33\%; 3) fase Comparing dengan indikator menjelaskan, menghubungan serta mengkaitkan masalah yang ditanyakan dengan masalah yang pernah dihadapi mencapai $85,83 \%$; 4) fase Contemplating dengan indikator menentukan maksud dan mendeteksi kebenaran jawaban pada penentuan jawaban mencapai 84,17\%. 5) fase Contemplating yaitu mendeteksi dan memperbaiki jika terjadi kesalahan serta menyimpulkan persoalan dengan benar mencapai $77,5 \%$. Pada kelas kontrol untuk indikator kemampuan berpikir reflektif, 1) fase Reacting dengan indikator menyebutkan apa yang diketahui dan apa yang ditanyakan serta menghubungkannya mencapai $82,50 \%$; 2) fase Reacting dengan indikator menjelaskan kecukupan informasi dan menjelaskan metode yang efektif untuk menyelesaikan soal mencapai 57,70\%; 3) fase Comparing dengan indikator menjelaskan, menghubungan serta mengkaitkan masalah yang ditanyakan dengan masalah yang pernah dihadapi mencapai $75,00 \%$; 4) fase Contemplating dengan indikator menentukan maksud dan mendeteksi kebenaran jawaban pada penentuan jawaban mencapai $75,00 \%$. 5) fase Contemplating yaitu mendeteksi dan memperbaiki jika terjadi kesalahan serta menyimpulkan pesoalan dengan benar mencapai $70,83 \%$.

Selain itu, pada hasil wawancara menunjukkan pada kelas eksperimen $75 \%$ peserta didik mampu menjawab pertanyaan sesuai dengan indikator berpikir reflektif dan kelas kontrol terdapat 41,67\% peserta didik yang mampu menjawab pertanyaan sesuai dengan indikator berpikir reflektif. Pada data observasi dan catatan lapangan kelas eksperimen menunjukkan 87,5\% peserta didik lebih memahami materi dan berpikir reflektif jika menggunakan model pembelajaran TAPPS (Thinking 
Aloud Pair Problem Solving) dan pada kelas kontrol mencapai 75,66\% peserta didik yang mampu memahami materi dan berpikir reflektif dengan menggunakan model pembelajaran konvensional.

Berdasarkan analisis data kualitatif dan data kuantitatif dapat dilakukan dengan cara membandingkan hasil penelitian kuantitatif dengan hasil penelitian data kualitatif yang diperoleh dari hasil tes akhir (post-test) kelas eksperimen dan kelas kontrol. Dalam penelitian kuantitatif, berdasarkan hasil uji hipotesis menyatakan bahwa terdapat perbedaan kemampuan berpikir reflektif dan pada penelitian kualitatif, berdasarkan hasil analisis per indikator menyatakan bahwa terdapat perbedaan prosentase kemampuan berpikir reflektif antara peserta didik kelas eksperimen dan kelas kontrol. Sehingga penelitian kualitatif yang dilakukan pada tahap kedua menghasilkan data kualitatif yang dapat mendukung, melengkapi, dan memperkuat data kuantitatif tentang kemampuan berpikir reflektif peserta didik. Karena sama-sama terdapat perbedaan antara kuantitatif dan kualitatif sehingga dapat disimpulkan bahwa penerapan metode pembelajaran TAPPS (Thinking Aloud Pair Problem Solving) berbantuan media LKPD pada materi bangun ruang balok dan kubus dapat meningkatkan kemampuan berpikir reflektif pada kelas eksperimen.

\section{PEMBAHASAN}

Berdasarkan data hasil tes kemampuan berpikir reflektif peserta didik yang diukur menggunakan hasil post-test. Berdasarkan hasil pengujian hipotesis diperoleh bahwa $\mathrm{H}_{0}$ ditolak, artinya terdapat perbedaan kemampuan berpikir reflektif peserta didik antara kelas eksperimen menggunakan metode pembelajaran TAPPS (Thinking Aloud Pair Problem Solving) dengan berbantuan media LKPD dan kelas kontrol dengan model pembelajaran konvensional. Perbedaan kemampuan berpikir reflektif peserta didik antara kelas eksperimen dan kelas kontrol juga dapat dilihat dari nilai post-test. kelas eksperimen mempunyai nilai rata-rata post-test sebesar 83 sedangkan pada kelas kontrol mempunyai nilai rata-rata post-test sebesar 72,12 sehingga dapat disimpulkan bahwa nilai rata-rata kemampuan berpikir reflektif kelas eksperimen lebih tinggi daripada kelas kontrol.

Dalam metode pembelajaran TAPPS (Thinking Aloud Pair Problem Solving) peserta didik saling berdiskusi kelompok secara berpasangan, saling bekerja sama dalam menyelesaikan persoalan dan lebih mudah untuk saling bertukar pendapat. Hal ini senada dengan Nuspitasri (2017: 104) mengatakan bahwa metode pembelajaran TAPPS (Thinking Aoud Pair Problem Solving) juga melatih kerjasama antar peserta didik pada langkah kerja kooperatif, mengerjakan lembar kerja secara berkelompok dan berpasangan akan membuat peserta didik merasa antusias dalam proses pembelajaran. Pembelajaran dengan berbantuan media LKPD mampu membuat peserta didik lebih aktif dalam proses pembelajaran. Hal ini senada dengan penelitian yang dilakukan Marsa, dkk (2016:52) mengatakan bahwa pembelajaran menggunakan media LKPD dapat meningkatkan keaktifan sebagaimana aktif dalam mencari, mengolah, mengontruksi, dan menggunakan pengetahuan peserta didik dalam proses pembelajaran.

Berdasarkan penelitian ini dapat disimpulkan bahwa metode pembelajaran TAPPS (Thinking

Aloud Pair Problem Solving) berbantuan media LKPD lebih efektif dalam meningkatkan kemampuan berpikir reflektif peserta didik dari pada model pembelajaran konvensional. Selain itu, pembelajaran berbantuan media LKPD juga dapat meningkatkan keaktifan peserta didik dalam mencari, mengolah, menggunakan pengetahuannya secara maksimal dalam kegiatan pembelajaran.

\section{SIMPULAN DAN SARAN}

Berdasarkan hasil analisis data kuantitatif dengan uji hipotesis menggunakan software SPSS 22 melalui uji Independent Sample T Test diperoleh nilai sig (2-tailed) $=0,005<0,025$ sehingga nilai $H_{0}$ di tolak atau $H_{1}$ diterima yang artinya terdapat perbedaan kemampuan berpikir reflektif antara peserta didik kelas eksperimen dan peserta didik kelas kontrol. Hasil post-test menunjukkan nilai rata-rata peserta didik kelas eksperimen sebesar 83. Sedangkan nilai rata-rata peserta didik kelas kontrol sebesar 72,17. Sehingga dapat disimpulkan bahwa terdapat perbedaan kemampuan 
berpikir reflektif antara peserta didik kelas eksperimen yang menggunakan metode pembelajaran Thinking Aloud Pair Problem Solving berbantuan media LKPD dan peserta didik kelas kontrol yang menggunakan metode pembelajaran konvensional.

Berdasarkan analisis data kualitatif yang diperoleh dari hasil wawancara didapatkan sebanyak $83,33 \%$ peserta didik merasa senang yang diberikan pembelajaran dengan metode Thinking Aloud Pair Problem Solving berbantuan media LKPD. Dari hasil analisis data wawancara sebesar $75 \%$ peserta didik kelas eksperimen sudah dikatakan memenuhi kelima indikator kemampuan berpikir reflektif. Berdasarkan hasil observasi, peserta didik kelas eksperimen terlihat lebih aktif dan antusias daripada peserta didik kelas kontrol. Hal ini juga didukung dari hasil catatan lapangan yang menunjukkan bahwa pada kelas ekperimen diperlihatkan oleh perilaku peserta didik yang baik, tanggapan peserta didik yang positif dan semangat peserta didik saat mengikuti kegiatan pembelajaran, keseriusan peserta didik dalam mengerjakan tugas dan diikuti dengan keadaan kelas yang kondusif . analisis data hasil post-test kemampuan berpikir reflektif peserta didik kelas eksperimen yang berkemampuan rendah sebesar $10 \%$, sedang sebesar 43,33\%, tinggi sebesar 46,67\%. Sedangkan rata-rata nilai peserta didik termasuk dalam kategori tinggi yaitu $83 \%$. Dari beberapa analisis data tersebut menunjukkan bahwa kemampuan berpikir reflektif masuk dalam kategori tinggi setelah penerapan dengan metode pembelajaran Thinking Aloud pair Problem Solving berbantuan media LKPD.

\section{DAFTAR RUJUKAN}

Rasyid, M. A. (2017). Profil berpikir Reflektif Siswa SMP dalam Pemecahan Masalah Pecahan Ditinjau dari Perbedaan gender. Seminar Internasional Pendidikan Matematika UNESA.

Johnson, S. D. \& Chung. (1999). The Effect Of Thinking Aloud Pair Problem Solving On The Troubleshooting Ability Of Aviation Technician Students. Journal of Agricultural Education.

Asdaniar. (2016). Pengaruh Penggunaan Lembar Kerja Peserta Didik Berbasis Peta Konsep Terhadap Motivasi Dan Hasil Belajar Peserta Didikkelas Vii Smpn 1 Awangpone. Program Pascasarjana Universitas Negeri Makasar.

Noer. (2010). Peningkatan Kemampuan Berpikir Kritis, Kreatif, Reflektif (K2R) Matematis Siswa SMP Melalui Pembelajaran Berbasis Masalah. Disertasi Jurusan Pendidikan Matematika FPMIPA Universitas Pendidikan Indonesia Bandung. 